KORNELIA CZERWIŃSKA

\title{
Funkcjonowanie wzrokowe osoby z progresywną słabowzrocznością - studium indywidualnego przypadku
}

\begin{abstract}
Kornelia Czerwińska, Funkcjonowanie wzrokowe osoby z progresywna stabowzrocznościq - studium indywidualnego przypadku [Visual functioning of an individual with progressive vision loss - a case study]. Interdyscyplinarne Konteksty Pedagogiki Specjalnej, nr 19, Poznań 2017. Pp. 271-289. Adam Mickiewicz University Press. ISSN 2300-391X. DOI: 10.14746/ikps.2018.20.14
\end{abstract}

The aim of the article is to present a subjective perspective of a person with congenital low vision who experienced gradual vision deterioration including total loss. A case study method was used in which the narrative biographic interview was the main technique of collecting data. In the analyzed narratives certain turning points were identified in the process of coping with the consequences of progressive impairment. Those were the situations when the subject was no longer able to perform a specific task which she had earlier performed under visual control. They made the subject realize the progressive nature of the disease and inevitably confronted her with the acquisition of permanent severe impairment. Those situations caused temporary disruption of her psychological balance and increased her demand for emotional support. With time, however, they also motivated the subject to use so far rejected rehabilitation devices and techniques. The lack of knowledge of functional implications of eye conditions (including reduced acuity and contrast sensitivity, field defects, light/dark adaptation problems etc.) among family members and significant others hindered the process of implementing optimal instrumental support to the subject.

KEY WORDS: vision loss, progressive vision loss, functional implications, case study, narrative interview 


\section{Wprowadzenie}

Niepełnosprawność uznawana jest za wielowymiarowe, złożone i wewnętrznie zróżnicowane zjawisko. Próby opisu i wyjaśnienia położenia życiowego osób z niepełnosprawnością wymagają więc uwzględnienia szeregu zróżnicowanych czynników, które pozostają względem siebie $\mathrm{w}$ dynamicznie zmieniających się relacjach. Obok właściwości osobowych, takich jak m.in.: wiek, płeć, kondycja zdrowotna, rasa, funkcje poznawcze, cechy osobowościowe i temperamentalne, styl życia, indywidualna hierarchia wartości i celów życiowych itp., istotny dla funkcjonowania tej grupy osób, w tym osiągnięcia poczucia dobrostanu psychofizycznego, jest kontekst społeczno-kulturowy, który warunkuje ilość i rodzaj zasobów przydatnych w radzeniu sobie z konsekwencjami posiadanej dysfunkcji1 ${ }^{1}$. Czynnikiem wyznaczającym w dużym stopniu kierunek analiz jest - wraz z rodzajem i stopniem uszkodzenia organizmu - charakter niepełnosprawności (wrodzona vs. nabyta), który generuje odmienne możliwości i potrzeby edukacyjno-rozwojowe, tym samym różnicuje zapotrzebowanie na oddziaływania wspierające (habilitacja vs. rehabilitacja).

Posiadanie niepełnosprawności o charakterze wrodzonym stanowi doświadczenie niewielkiej części omawianej populacji. Mimo iż medyczne i prawne kryteria klasyfikacji osób z niepełnosprawnością są w poszczególnych krajach dość odmienne, to analizy danych statystycznych jednoznacznie wskazują, że ok. 97\% z nich nabyło dysfunkcję w biegu życia w wyniku urazu, choroby i (lub) zmian związanych z wiekiem². Według sondaży krajowych mniej niż 20\% osób posiada niepełnosprawność od urodzenia, u pozostałych pojawiła się ona przede wszystkim na skutek długotrwałej choroby, najczęściej $\mathrm{w}$ fazie dorosłości, zwłaszcza $\mathrm{w}$ wieku senioralnym ${ }^{3}$.

1 S. Rudnicki, Niepetnosprawność i złożoność, „Studia Socjologiczne” 2014, nr 2(213), S. $49-50$.

2 D. Goodley, Disability Studies. An Interdisciplinary Introduction, MPG Books Group, Bodmin and King's Lynn, London 2011, s. 1.

${ }^{3}$ J. Bartkowski, Położenie społeczno-ekonomiczne i jakość życia osób niepetnosprawnych w Polsce, [w:] Polscy niepetnosprawni. Od kompleksowej diagnozy do nowego modelu 
Zmiany demograficzne zachodzące we współczesnych społeczeństwach powodują więc, że osiągnięcie statusu osoby $\mathrm{z}$ niepełnosprawnością stanowi wieloletni proces, $\mathrm{w}$ którym postęp schorzenia doprowadza sukcesywnie do utraty sprawności w określonym obszarze.

Wraz ze wzrostem liczby chorób przewlekłych i zwyrodnieniowych doprowadzających stopniowo do niepełnosprawności obserwuje się w pedagogice specjalnej i naukach o zdrowiu coraz większe zainteresowanie subiektywnym spostrzeganiem i oceną własnej sytuacji życiowej przez osoby dorosłe. Powolne nabywanie dysfunkcji sprawia, że dotychczasowe cele zazwyczaj tracą swoją aktualność, a wizja przyszłej egzystencji podlega przekształceniom związanym ze zmianami w systemie wartości. Znaczenie choroby wyznaczane jest poprzez jej konsekwencje odczuwane i wartościowane przez daną osobę $\mathrm{w}$ danych okolicznościach życiowych ${ }^{4}$, stąd istotne jest uchwycenie $\mathrm{w}$ badaniach naukowych naturalnego kontekstu doświadczeń umożliwiające pogłębione opisanie i zrozumienie danego zagadnienia ${ }^{5}$. Analiza osobistych doświadczenia jednostek i grup relacjonowanych $\mathrm{w}$ autobiograficznych opowieściach ujawnia znaczenie, jakie procesowi chorobowemu i nabywaniu niepełnosprawności nadają poszczególne osoby, jak również pozwala poznać subiektywny wymiar ich trudności, potrzeb, oczekiwań, strategii radzenia sobie. Narracje osób nabywających niepełnosprawność mogą mieć różny charakter i cel. Niektóre autonarracyjne wypowiedzi odwołują się do przyczyn schorzenia i jego skutków w codziennym życiu, inne stanowią relację na temat zmian w tożsamości osobistej i społecznej, ułatwiając osobie zrozumienie przemian dokonujących się w obrębie własnego Ja. Narracje mogą także ukazywać związek między doświadczeniami danej osoby a znacze-

polityki społecznej, red. B. Gąciarz, S. Rudnicki, Wydawnictwa Akademii Górniczo-Hutniczej, Kraków 2014, s. 51-52.

${ }^{4}$ M. Blaxter, Zdrowie, przeł. M. Okła, Wydawnictwo Sic!, Warszawa 2009, s. $88-89$.

${ }^{5}$ U. Flick, Jakość w badaniach jakościowych, przeł. P. Tomanek, Wydawnictwo Naukowe PWN, Warszawa 2011, s. 14. 
niami kulturowo-społecznymi przypisywanymi zdrowiu i chorobie, sprawności i niepełnosprawności ${ }^{6}$.

Analiza sposobu konstruowania rzeczywistości przez osobę nabywającą stopniowo niepełnosprawność ma dużą wartość poznawczą dla pedagogiki specjalnej, gdyż treść i zakres dostarczanego wsparcia $\mathrm{w}$ takich sytuacjach są determinowane nie tylko przez dynamikę choroby, ale przede wszystkim przez potrzeby i oczekiwania tej osoby, które wymagają odpowiedniego rozpoznania i zrozumienia. Celem artykułu uczyniono więc przedstawienie narracji wyrażających subiektywną perspektywę osoby, która stopniowo w cyklu życiowym traciła wzrok, ze zwróceniem szczególnej uwagi na sens, znaczenie i wartość przypisywane wybranym doświadczeniom $\mathrm{w}$ kontekście procesu nabywania statusu osoby z trwałą niepełnosprawnością.

\section{Specyfika stopniowej utraty wzroku}

Funkcjonalne konsekwencje nabycia niepełnosprawności wzroku zależne są od wielu czynników, wśród których za podstawowe uważa się: fazę życia, sposób utraty widzenia (nagły vs. stopniowy), zakres utraty (całkowite vs. częściowe), zasoby osobowe, w tym właściwości osobowościowe, tryb życia, zainteresowania7. W przypadku stopniowej utraty wzroku istotne znaczenie dla przybrania przez to doświadczenie znamion traumy mają takie czynniki, jak m.in.: przebieg procesu diagnostycznego, niekorzystne rokowania, czas trwania choroby, poczucie osamotnienia związane z częstym

${ }^{6}$ M. Bury, Illness narratives: fact or fiction? "Sociology of Health and Illness" 2001, nr 23, s. 267-280.

7 T. Majewski, Tyflopsychologia rozwojowa. Psychologia dzieci niewidomych i stabo widzacych, Polski Związek Niewidomych, Warszawa 2002, s. 18-19; I. Chrzanowska, Pedagogika specjalna. Od tradycji do wspótczesności, Oficyna Wydawnicza „Impuls”, Kraków, 2015, s. 186; M. Zaorska, Tyflopedagog wobec problemu aktywności życiowej zawodowej i prozawodowej osób dorostych z niepetnosprawnością wzrokowa, Wydawnictwo Edukacyjne Akapit, Toruń 2015, s. 24-26. 
pobytem w szpitalu i powtarzającymi się zabiegami czy procedurami medycznymi itp. ${ }^{8}$. Także sposób, w jaki dochodzi do pogłębiania się dysfunkcji (ciągły vs. skokowy), bezpośrednio oddziałuje na stopień dezorganizacji struktur psychicznych. Mniejsze obciążenie emocjonalne skutkujące negatywnymi reakcjami emocjonalnymi o umiarkowanym natężeniu obserwuje się przy płynnym postępie choroby, często trudnym do zarejestrowania przez osobę w codziennym funkcjonowaniu. Natomiast nagłe i znaczne pogorszenie się widzenia w postaci wyraźnie odczuwalnego pogłębienia się dotychczasowych trudności lub pojawienia się nowych objawów chorobowych pociąga za sobą stan silnego dystresu. Zachwianiu ulegają przekonania o przewidywalności zdarzeń, obniża się poczucie kontroli i sprawstwa, zmniejsza się autonomia wykonawcza, narasta obawa przed całkowitym ociemnieniem, wyznaczane dotąd cele życiowe wydają się być niemożliwe do osiągnięcia, a to łącznie może prowadzić do silnego kryzysu emocjonalnego wiążącego się z podważeniem sensu własnej egzystencji.

Trudności doświadczane przez osobę z progresywną słabowzrocznością we wszystkich sferach codziennego funkcjonowania, w tym zwłaszcza w orientacji przestrzennej i lokomocji, samodzielnym prowadzeniu gospodarstwa domowego, wykonywaniu precyzyjnych czynności, utrzymywaniu kontaktów interpersonalnych, nasilają niepokój, lęk, niepewność, poczucie bezradności i zależności ${ }^{9}$. Brak akceptacji zachodzących zmian oraz niedostatek pomocy i wsparcia społecznego w takiej sytuacji może skutkować depresją ${ }^{10}$. Należy podkreślić, że wsparcie społeczne może z powodzeniem chronić osoby z zaburzeniami widzenia przed radykalnym spadkiem poczucia zadowolenia z własnego życia, jak również ograni-

8 Por. K. Devine, B. Reed-Knight, K. Loiselle, N. Fenton, R. Blount, Posttraumatic growth in young adults who experienced serious childhood illness: A mixed-methods approach, "Journal of Clinical Psychology in Medical Settings” 2010, nr 17, s. 340-348.

${ }^{9}$ E. Stanikowska, Psychologiczne aspekty stabowzroczności, „Kontaktologia i Optyka Okulistyczna" 2008, nr 3(19), s. 20.

${ }^{10}$ Por. R. Casten, B. Rovner, Depression in age-related macular degeneration, „Journal of Visual Impairment \& Blindness" 2008, vol. 102, nr 10, s. 591-599. 
czać typowe problemy dnia codziennego ${ }^{11}$. Efektywność wsparcia ściśle zależy od tego, czy jest ono adekwatne pod względem treści i zakresu do określonej sytuacji, co w konsekwencji przynosi satysfakcję osobie słabowidzącej. Udzielanie pomocy nadmiernej, niedostatecznej lub ukierunkowanej na niewłaściwy obszar funkcjonowania osoby wspieranej nie tylko jest nieskuteczne w radzeniu sobie z sytuacją trudną, co wręcz pociąga za sobą negatywne następstwa, które mogą wywierać większy wpływ na stan zdrowia psychicznego osoby znajdującej się w kryzysie ${ }^{12}$. W przypadku stopniowego nabywania niepełnosprawności wzroku często obserwowane są reakcje otoczenia oparte na współczuciu i jawnym okazywaniu litości, które prowadzą do działań nadopiekuńczych. Tego typu działania, podobnie jak unikanie kontaktu i dystansowanie się wobec problemu, mogą wynikać także z poczucia braku kompetencji w zakresie udzielania wsparcia osobie tracącej wzrok. Dodatkową trudnością jest fakt, że możliwości wzrokowe osoby z progresywną słabowzrocznością dynamicznie się zmieniają, co również implikuje konieczność elastycznego modyfikowania udzielanej pomocy. Kluczową kwestią jest więc dobry wgląd samej osoby słabowidzącej pozwalający jej trafnie określić aktualne sprawności wzrokowe oraz umiejętność precyzyjnego komunikowania indywidualnych potrzeb i oczekiwań. Z kolei otoczenie, w tym zwłaszcza członkowie najbliższej rodziny, muszą stale rozwijać kompetencje w obszarze udzielania odpowiednio dopasowanego wsparcia. Podstawą do zidentyfikowania aktualnych możliwości i potrzeb osoby stopniowo nabywającej niepełnosprawność wzroku jest znajomość bieżących wyników funkcjonalnej oceny widzenia, w tym poznanie wpływu następstw danego schorzenia układu wzrokowego na codzienne działania osoby.

11 Por. S. Steuden, Z psychologicznej problematyki zdrowia i choroby, [w:] Jak świata mniej widzę: zaburzenia widzenia a jakość życia, red. P. Oleś, S. Steuden, J. Toczołowski, Towarzystwo Naukowe Katolickiego Uniwersytetu Lubelskiego, Lublin 2002b, s. 35-36.

12 C. B. Wortman, Posttraumatic growth: Progress and problems, „Psychological Inquiry" 2004, nr 15, s. 81-90. 
Wśród najczęstszych funkcjonalnych następstw schorzeń układu wzrokowego wymienia się: obniżenie ostrości wzroku, zaburzenia wrażliwości na kontrast, ubytki w polu widzenia, zaburzenia wrażliwości na światło, problemy $\mathrm{z}$ adaptacją do zmiennych warunków oświetleniowych, zaburzenia widzenia zmierzchowego, zaburzenie percepcji barw, oczopląs itp. ${ }^{13}$. Obniżenie ostrości wzro$\mathrm{ku}$ to jedno z podstawowych kryteriów medycznych i prawnych klasyfikacji uszkodzeń wzroku. Ostrość wzroku rozumiana jest jako zdolność spostrzegania obiektów i ich elementów wewnętrznych, a jej osłabienie ma poważne konsekwencje dla możliwości wykonywania tak precyzyjnych działań, jak czytanie, pisanie, rysowanie, mierzenie i inne czynności związane z procesem uczenia się opartego na obserwacji, naśladownictwie, pracy z materiałami wizualny$\mathrm{mi}^{14}$. Przy znacznym zaawansowaniu schorzenia obniżenie ostrości wzroku jest zazwyczaj tak poważne, że rzutuje negatywnie nie tylko na zdolność prawidłowej identyfikacji i różnicowania drobnych obiektów i ich właściwości (np. rozpoznanie liter czy twarzy), lecz ujemnie oddziałuje na wszystkie sfery funkcjonowania osoby, generując trudności $\mathrm{w}$ orientacji $\mathrm{w}$ przestrzeni, samodzielnym przemieszczaniu się, efektywnym wykonywaniu czynności dnia codziennego, kontaktach społecznych. O znaczeniu wskaźników ostrości wzroku dla funkcjonowania osoby świadczyć mogą badania przeprowadzone wśród pacjentów z zaćmą, w których wykazano, że osoby o obiektywnie wyższej ostrości mają wyższe ogólne poczucie jakości życia oraz poczucie jakości życia w chorobie ${ }^{15}$. Po-

${ }^{13}$ Szczegółowe informacje nt. wymienionych konsekwencji zostały zawarte w m.in. M. Walkiewicz-Krutak, Stabowzroczność w aspekcie klinicznym i funkcjonalnym, [w:] Tyflopedagogika wobec wspótczesnej przestrzeni edukacyjno-rehabilitacyjnej, red. K. Czerwińska, M. Paplińska, M. Walkiewicz-Krutak, Wydawnictwo Akademii Pedagogiki Specjalnej, Warszawa, 2015, s. 198-219. W artykule wyjaśniono w sposób skrótowy tylko te następstwa funkcjonalne, które bezpośrednio odnoszą się do prezentowanego $\mathrm{w}$ tekście przypadku.

${ }^{14} \mathrm{R}$. Walthes, Einführung in die Blinden- und Sehbehindertenpädagogik, Reinhardt Verlag, München 2005, s. 50-54.

${ }^{15}$ P. Oleś, M. Oleś, Poczucie jakości życia u pacjentów chorych na zaćmę, [w:] Jak świata mniej widzę: zaburzenia widzenia a jakość życia, red. P. Oleś, S. Steuden, J. Toczo- 
dobnie badania zrealizowane wśród osób chorych na jaskrę dowiodły, że wzrostowi ostrości wzroku odpowiadał lepszy ogólny wskaźnik poczucia jakości życia, poziomu samooceny realnej, potrzeby poszukiwania kontaktów interpersonalnych itp. Ponadto poprawie ostrości widzenia $\mathrm{u}$ badanych towarzyszyło obniżenie klinicznych wymiarów choroby takich, jak: poczucie beznadziejności, poczucie osamotnienia, lęk rozpatrywany jako stan ${ }^{16}$.

Z obniżeniem ostrości wzroku często współwystępuje zaburzenie wrażliwości na kontrast, które funkcjonalnie powoduje szereg trudności w rozpoznawaniu sąsiadujących obiektów nieznacznie różniących się pod względem oświetlenia i natężenia barw, w tym $\mathrm{w}$ wyodrębnianiu przedmiotu z tła. Wrażliwość na kontrast, podobnie jak ostrość wzroku, znacząco wpływa na jakość widzenia.

Kolejnym poważnym następstwem funkcjonalnym schorzeń i uszkodzeń układu wzrokowego utrudniającym planowanie, wykonanie i kontrolę poprawności realizacji wielu czynności są ograniczenia $\mathrm{w}$ polu widzenia (tzw. mroczki). Ich bezpośrednie skutki zależne są od wielkości oraz obszaru występowania ubytku. W przypadku uszkodzeń centralnej części pola widzenia osoba słabowidząca doświadcza przede wszystkim obniżenia ostrości wzro$\mathrm{ku}$ i trudności $\mathrm{w}$ rozpoznawaniu barw, zaś przy ograniczeniach w obszarach obwodowych podstawowym problemem jest orientacja $\mathrm{w}$ przestrzeni, zwłaszcza $\mathrm{w}$ terenie nieznanym, dostrzeganie przeszkód, obserwacja obiektów o znacznej wielkości. Dla niektórych schorzeń typowe są mroczki rozsiane, czyli ubytki znajdujące się w różnych obszarach pola widzenia ${ }^{17}$.

Wśród licznych następstw funkcjonalnych doświadczanych przez osoby słabowidzące dotkliwe $\mathrm{w}$ codziennych działaniach są

łowski, Towarzystwo Naukowe Katolickiego Uniwersytetu Lubelskiego, Lublin 2002, s. 104-105.

${ }^{16}$ S. Steuden, Poczucie jakości życia u pacjentów chorych na jaskrę, [w:] Jak świata mniej widzę: zaburzenia widzenia a jakość życia, red. P. Oleś, S. Steuden, J. Toczołowski, Towarzystwo Naukowe Katolickiego Uniwersytetu Lubelskiego, Lublin 2002a, s. 128-129.

${ }_{17}$ B. Golemba, Dostosowanie otoczenia do potrzeb dziecka stabo widzacego, „Niepełnosprawność i Rehabilitacja" 2007, nr 2, s. 72-73. 
również zaburzenia wrażliwości na światło przyjmujące postać nadreaktywności (światłowstręt, olśnienia) lub zwiększonego zapotrzebowania na oświetlenie. W przypadku nadwrażliwości brak możliwości regulacji natężenia światła może u osoby wywoływać mocny dyskomfort, ból, czy wręcz zupełnie uniemożliwiać korzystanie ze wzroku. Podobne problemy wiążą się ze zjawiskiem olśnienia, czyli nagłego, stosunkowo krótkotrwałego obniżenia ostrości wzroku pod wpływem światła odbitego od gładkiej powierzchni lub bezpośrednio płynącego z danego źródła18. Zarówno nadwrażliwość, jak i światłolubność sprawiają, że jakość widzenia jest w znacznym stopniu zależna od aktualnych warunków panujących w otoczeniu fizycznym, które podlegają częstym, nieraz gwałtownym, zmianom i w związku z tym są dość trudne do kontroli, zwłaszcza w przestrzeni otwartej. Duża zmienność w oświetleniu generuje trudności także dla tych osób słabowidzących, u których schorzenie układu wzrokowego charakteryzuje się zaburzeniem adaptacji do światła i ciemności, co zazwyczaj oznacza potrzebę dłuższego czasu przystosowania się do odmiennych warunków, zaś w skrajnych sytuacjach może powodować funkcjonalne niewidzenie.

Wskazane powyżej i inne następstwa schorzeń układu wzrokowego stanowią jedną z grup czynników determinujących stopień i sposób posługiwania się wzrokiem przez osoby słabowidzące w nauce, pracy, rozrywce, czynnościach dniach codziennego. Znajomość i poprawne rozumienie ich specyfiki pozwala osobie stopniowo tracącej wzrok i jej otoczeniu społecznemu na właściwy dobór strategii radzenia sobie $\mathrm{z}$ trudnościami, tym samym zmniejszając poczucie bezradności i braku kontroli. Wiedza członków rodziny osoby z progresywną słabowzrocznością na temat tego, jakie posiada ona możliwości wzrokowe i jakie problemy mogą potencjalnie pojawić się przy danym typie działania w określonych warunkach zewnętrznych, minimalizuje ryzyko wykształcenia postawy nadopiekuńczości, jak również udzielania pomocy w stopniu niewystarczającym.

18 M. Walkiewicz-Krutak, op. cit., s. 213-214. 


\section{Funkcjonowanie osoby stopniowo tracącej wzrok - studium przypadku}

W badaniach własnych, których głównym celem było poznanie subiektywnego znaczenia przypisywanego doświadczaniu stopniowej utraty wzroku w biegu życia, wykorzystano metodę studium indywidualnego przypadku. Metoda ta rekomendowana jest $\mathrm{w}$ analizach cyklu życia jednostek, zwłaszcza w sytuacjach, w których eksplorowany obszar ma wielowymiarowy, złożony charakter, a pogłębione zrozumienie danego zjawiska wymaga bezpośrednich odniesień do konkretnych czynników kontekstowych ${ }^{19}$.

Podstawową techniką gromadzenia danych uczyniono biograficzny wywiad narracyjny, który został przeprowadzony zgodnie ze wskazówkami metodycznymi Fritza Schützego, tj. obejmował trzy etapy: fazę opowieści głównej, fazę pytań wewnętrznych oraz zewnętrznych ${ }^{20}$. Należy podkreślić, że część zasadnicza wywiadu była bardzo rozbudowana - narratorka obszernie opisywała swoje doświadczenia życiowe związane $\mathrm{z}$ pogarszaniem się widzenia, podawała najistotniejsze $\mathrm{w}$ jej ocenie wydarzenia, starając się zachować ich porządek chronologiczny oraz ukazywała kontekst społeczno-kulturowy, w tym polityczno-gospodarczy, w którym miały one miejsce. Najprawdopodobniej czynnikiem, który przyczynił się do dużej otwartości narratorki $\mathrm{w}$ przebiegu całej procedury badania było poczucie komfortu wynikające stąd, że badaczka była osobą już w pewnym stopniu jej znaną; za wyraz zaufania i poczucia bezpieczeństwa uznać można dość często pojawiający się w wypowiedziach zwrot „Tobie mogę to opowiedzieć". Przekonanie o pozytywnym nastawieniu przyszłej narratorki do badaczki i realizowanych badań pozwoliło na skrócenie czynności początkowych podejmowanych w celu nawiązania pozytywnej relacji i przedstawienie w zwięzły sposób

19 R.K. Yin, Studium przypadku w badaniach naukowych. Projektowanie i metody, przeł. J. Gilewicz, Wydawnictwo Uniwersytetu Jagiellońskiego, Kraków 2015, s. 36-49.

${ }^{20}$ E. Kos, Wywiad narracyjny jako metoda badań empirycznych, [w:] Badania jakościowe w pedagogice. Wywiad narracyjny i obiektywna hermeneutyka, red. D. Urbaniak-Zając, E. Kos, Wydawnictwo Naukowe PWN, Warszawa 2013, s. 91-116. 
zachęty generującej narrację: „Opowiedz mi o swoim życiu, ponieważ chcę zrozumieć doświadczenie utraty wzroku, które przeżyłaś".

Analiza danych z wywiadów biograficznych może być skoncentrowana na samej biografii i jej strukturze albo na wybranych treściach pojawiających się $\mathrm{w}$ wypowiedziach ${ }^{21}$. Interpretując materiał narracyjny z transkrypcji wywiadu, nie starano się dokonać całościowej rekonstrukcji biografii osoby stopniowo tracącej wzrok, lecz analizowano szereg wątków ${ }^{22}$ wyjaśniających specyfikę nabywania statusu osoby $\mathrm{z}$ niepełnosprawnością wzroku. Jeden z kierunków analizy wyznaczyły te kwestie zawarte w opowieści, które pozwoliły uzyskać odpowiedzi na następujące pytania badawcze:

- jakie miejsce zajmuje doświadczenie trajektoryjne (nabycie niepełnosprawności wzroku) w całości doświadczeń biograficznych narratorki?

- jakie wydarzenia stanowiły punkty zwrotne w trajektorii stopniowej utraty wzroku?

Wywiad trwał cztery godziny. Narratorką była 46-letnia kobieta z zespołem Marfana, czyli genetyczną chorobą tkanki łącznej, charakteryzującą się dużą zmiennością fenotypową. W przebiegu tej choroby zmiany narządowe obejmują cały organizm, zaś główne objawy związane z narządem wzroku to m.in.: krótkowzroczność, astygmatyzm, zwichnięcie soczewki, płaska rogówka, hipoplazja tęczówki, zwiększony wymiar gałki ocznej w osi długiej, odwarstwienie siatkówki, jaskra, zaćma ${ }^{23}$. Osoba badana, doświadczając

${ }^{21}$ E. Soroko, Wywotywanie autonarracji w badaniach psychologicznych. Ocena (auto)narracyjności wypowiedzi, Wydawnictwo Naukowe Uniwersytetu Adama Mickiewicza, Poznań 2009, s. 50-51.

22 Jedną z bardziej interesujących kategorii tematycznych stanowiły wątki emancypacji, w tym wypracowania przez narratorkę strategii pokonywania sił opresyjnych związanych z niepełnosprawnością. Kwestie te przedstawiono szerzej w innym artykule: K. Czerwińska, Wątki emancypacyjne w biegu życia osoby stopniowo tracacej wzrok, „Interdyscyplinarne Konteksty Pedagogiki Specjalnej” 2015, nr 10, s. 127-153.

23 Szerzej na temat etiologii, objawów klinicznych i przebiegu zespołu Marfana w m.in. B.T. Tinkle, H.M. Saal, the Committee on Genetics, Health Supervision for Children With Marfan Syndrome, „Pediatrics” 2013, Vol. 132, nr 4, s. 1059-1072. 
od urodzenia problemów zdrowotnych, w tym okulistycznych, całkowicie utraciła wzrok we wczesnej dorosłości. Ukończyła wyższe studia ekonomiczne. $W$ okresie realizacji badań pracowała na otwartym rynku pracy na stanowisku eksperckim, pozostawała w wieloletnim związku małżeńskim, była bezdzietna, wraz z mężem prowadziła gospodarstwo domowe w dużej aglomeracji miejskiej.

Narracje relacjonujące wydarzenia biograficzne z okresu wczesnego dzieciństwa i adolescencji są pełne tzw. komentarzy teoretycznych, poprzez które badana przekazuje własne opinie na temat swojego ówczesnego sposobu działania, wykazując się wysokim poziomem refleksyjności. W jej percepcji stopniowe nabywanie niewidzenia, które było jedną z konsekwencji posiadania poważnej choroby układowej, w pewnym stopniu stało się centralną osią jej ścieżki biograficznej: w wyraźny sposób oddziaływało na wypełnianie ról szkolnych, determinowało kontakty z rówieśnikami, kształtowało w pewnym zakresie relacje $\mathrm{z}$ najbliższymi członkami rodziny, a przede wszystkim wpływało na przyjmowane plany i wyznaczane cele życiowe. Zarazem badana zauważa, że praktyka życia codziennego nie była zdominowana przez kwestie zdrowotne i stałą obawę przed dalszym postępem choroby. Nabywanie niewidzenia miało postać powolnego, wieloletniego procesu, którego charakter był dość rozmyty. Temat potencjalnej utraty wzroku w przyszłości powracał w momentach kontrolnych wizyt lekarskich, licznych hospitalizacji i poddawania się procedurom medycznym. Za kluczowe w przebiegu trajektorii badana uznała takie sytuacje, w których niespodziewanie konfrontowała się z faktem, że jej możliwości wzrokowe uległy zmniejszeniu i nie może w sposób efektywny, szybki i bezpieczny wykonać zadania, które wcześniej nie nastręczało jej trudności.

Tak bardzo dokładnie to nie pamiętam, jak zmieniat się mój sposób widzenia, ale jako dziecko widziatam inaczej, czytajac, ogladając rysunki w ksiażce, dostownie jeździłam nosem po kartce. Bardzo blisko trzymałam te rzeczy, które oglądałam. Później, po kilku zabiegach okulistycznych, dostatam okulary, to znaczy inny rodzaj niż te, które dotychczas nosiłam, bo dostałam plusy i wtedy zaczętam troszkę dalej ogladać różne rzeczy, oczywiście widząc stabo. I tak 
było przez wiele lat, nie widziatam, nie rejestrowałam żadnych zmian w tym swoim widzeniu. Do momentu, kiedy w liceum nastapiło odklejenie siatkówki w jednym oku, przy czym to też nie spowodowato od razu jakiegoś dużego pogorszenia widzenia, tylko taka jakby "firankę". No, ale później zabieg, przyklejanie tej siatkówki, przerwa spora i okazało się po powrocie do szkoty po kilku miesiacach, że jednak, mimo że nie widzę tak bardzo różnicy w moim widzeniu, to ta różnica jest. Nagle się okazało, że wcześniej z pierwszej ławki widziałam na tablicy w miare swobodnie, teraz siedzac przed sama prawie tablica, niestety, ale jeśli nie śledzitam ręki nauczycielki i nie stuchatam tego, co ona mówi, to nie byłam w stanie przeczytać tego, co pisze. Chodziłam do zwykłej szkoły. W liceum najbardziej zauważyłam to na matematyce, na której nauczycielka mnóstwo i szybko pisała, pisata tak szybko, że nie było szansy zajrzenia do zeszytu koleżanki, żeby przepisać, tylko trzeba byto na bieżaco, to byt dla mnie duży szok po powrocie ze szpitala. To mi bardzo uzmystowiło, $\dot{z}$ e jest różnica, że widzę gorzej.

W retrospektywnej ocenie narratorki sytuacje takie, jak przedstawiona $\mathrm{w}$ powyższym fragmencie wypowiedzi, odegrały dużą rolę $\mathrm{w}$ procesie przystosowania do faktu nabywania niepełnosprawności. Bezpośrednio po ich wystąpieniu następowało u badanej zaburzenie równowagi emocjonalnej o różnym nasileniu, od krótkotrwałego obniżenia nastroju po epizod depresyjny w okresie wczesnej dorosłości, który skutkował rocznym pobytem w mieszkaniu rodziców i całkowitą izolacją od rówieśników. Jednak w dalszej perspektywie czasowej, po przezwyciężeniu problemów natury emocjonalnej, wydarzenia te stawały się dla narratorki impulsem do podjęcia nowych działań, w tym motywowały ją do opanowania przydatnych technik rehabilitacyjnych, które wcześniej odrzucała jako metody przeznaczone dla osób o mniejszym niż jej potencjale wzrokowym. Łącznie w wypowiedziach narratorki zostało przywołanych około dziesięciu tego typu sytuacji, które stawały się w jej opinii punktami zwrotnymi $\mathrm{w}$ adaptacji do stopniowej utraty wzroku.

Wydarzenia te opisywane są w narracjach w sposób bardzo szczegółowy, wręcz drobiazgowy, a szereg miejsca badana poświęca w nich na deskrypcję i wyjaśnienie swoich przeżyć emocjonal- 
nych. W przezwyciężeniu kryzysów emocjonalnych i aktywnym włączeniu się w proces rehabilitacji pomagały życzliwe reakcje osób najbliższych, a zwłaszcza zrozumienie specyfiki trudności, jakich badana na co dzień doświadczała z powodu następstw funkcjonalnych posiadanego schorzenia. Narratorka podkreśla, że otrzymała wiele pomocy i wsparcia od innych w okresach, gdy dochodziło do obniżenia ostrości wzroku, a jej zdolność spostrzegania szczegółów była niewystarczająca do wykonania precyzyjnych czynności. Rodzice i znajomi, kierując się głównie wiedzą potoczną i intuicją, przewidywali, jakie działania mogą być dla niej problematyczne czy wręcz nieosiągalne i stosowali proste rozwiązania zaradcze lub wspierające np. odczytywali jej informację z ulotki lekarstwa, stosowali powiększony druk w etykietach produktów kuchennych, zmniejszali dystans fizyczny podczas rozmowy itp. Natomiast pozostałe następstwa funkcjonalne posiadanego schorzenia, które pojawiały się lub zwiększały swoje nasilenie $\mathrm{w}$ postępie procesu chorobowego, okazały się trudne do wyjaśnienia dla osób postronnych, stąd udzielana pomoc zazwyczaj była niedostateczna lub nieadekwatna. Do tego typu następstw funkcjonalnych należały: zaburzenia adaptacji do zmiennych warunków oświetleniowych, ślepota zmierzchowa, mroczki rozsiane.

Mroczek to nie jest czarna kropka czy plamka, absolutnie nie. Mroczka w ogóle się nie rejestruje. To co jest wokoto tego ubytku w polu widzenia, wokót tego mroczka, przenosi się na ten mroczek, jakby uśredniato się to co wokót. Wefekcie patrzac, widze tło jakby otoczenia, nie widze mroczka, ja nawet nie wiedziałam, że mam mroczek, tylko kiedyś taka mała plamka świetlna od świecy jakoś tak mi ustawiła się na wysokości tego ubytku i ja wtedy zauważyłam, że jak tak patrze, to ona mi znika. Zupetnie. Pewnie z tego powodu zdarzało mi się czasem coś tam potracić czy stuknąć, ale ja tego nie tączyłam z tym mroczkiem, nie zauważałam tego. Może dlatego, że to byt taki jeden mroczek, konkretne, nieduże miejsce w polu widzenia, z czasem człowiek się przyzwyczaja $i$ odruchowo nawet łapałam się na tym, że jak czegoś szukałam, to ustawiałam oczy tak, żeby spojrzeć poniżej tego mroczka albo powyżej tego mroczka i robie to odruchowo, zupetnie już potem tego nie kontrolując. Próbowałam to rodzicom wyjaśniać, ale...to po prostu trudno jest sobie widzącej osobie wyobrazić. 
(...) Byłam w takiej grupie oazowej, gdzie były czytania Pisma Świętego, każdy po fragmencie coś tam czytat i na szczéście koleżanka prowadzaca wiedziata, że ja nie jestem w stanie przeczytać takim matym drukiem w średnio oświetlonym miejscu, to po prostu mnie omijata. Wszyscy nie mogli zrozumieć, dlaczego, bo nikt tego nie tłumaczyt... Ja też nie wpadłam wtedy na to, żeby wyttumaczyć... to było dla mnie krępujące... Na przykład w pewnym momencie, musieliśmy gdzieś tam z jednego do drugiego pomieszczenia przejść, gdzie byto bardzo ciemno, ta znaczy dla mnie, bo inni widzieli, ale dla mnie to już było zupetnie ciemno, no $i$ się zatrzymatam $i$ nie byłam $w$ stanie iść $i$ też było zdziwienie "No, a Ty co?", a ja "No, niestety nie widze". "Jak to nie widzisz?". "No nie widze, bo tu jest ciemno", "Ale tu nie jest ciemno". Byt to dla mnie problem. Gdzieś tam na wyjeździe też z dwoma koleżankami się trzymałam, gdzie one wiedziaty, że jak przechodzimy ze słonca do jakiegoś pomieszczenia, to one wiedziaty, że ja w tym momencie jestem totalnie bezradna i muszę się ich przytrzymać przy chodzeniu, ale... inni nie wiedzieli. Pozostała część grupy nie wiedziała, tacznie z tym, że jakieś śmieszne komentarze na nasz temat bywaty typu "papużki-nierozłaczki” albo coś tam. Ludzie nie zauważyli tego, że one mi po prostu pomagaja, bo nikt tego po mnie nie widziat. To w sumie byty takie mieszane uczucia, z jednej strony chciałam, żeby nie wiedzieli, a $z$ drugiej bardzo mnie stresowaty te sytuacje, w których to wychodzito.

W powyższych wypowiedziach uwidacznia się strategia maskowania posiadanych problemów wzrokowych, którą narratorka stosowała w okresie dorastania i wczesnej dorosłości w wielu sytuacjach publicznych, nawet wówczas, gdy narażało ją to na niebezpieczeństwo (np. samodzielne przemieszczanie się $\mathrm{w}$ mieście po zmierzchu bez użycia białej laski) lub wykluczało efektywne wykonanie danego zadania (np. rezygnacja z odbioru pisemnej informacji $\mathrm{z}$ powodu niechęci do zastosowania lupy). Z obecnej perspektywy badana interpretuje swoje zachowania jako przejaw bezsilnego oporu wobec postępu choroby oraz zaprzeczania wynikającego z silnych barier emocjonalnych przed przyjęciem statusu osoby z trwałą, poważną niepełnosprawnością. Uważa, że szczególną egzemplifikacją tych problemów było trwające $u$ niej kilka lat aktywne unikanie wykorzystywania technik poruszania się opartych na dotyku i słuchu. 
Pomyślenie o tym, żebym wzięła $i$ wyjęta laskę, o... to było kłopotem. A laske miałam. Dostatam ją dużo, dużo wcześniej, gdy zapisatam się do Polskiego Zwiazku Niewidomych. Wtedy była taka tendencja, że jak się zostawało członkiem PZN, to z automatu dostawało się laskę. Pamiętam, że to byt dla mnie szok, choć może nawet mniej dla mnie, co dla mojej mamy, która była tym przerażona, bo wtedy naprawde jeszcze sporo widziałam, to byt poczatek liceum. Zapisatam się do PZN-u, dlatego żeby zapisać się do biblioteki, żeby wypożyczać ksiażki, bo już wtedy byto problemem dtu̇̇sze czytanie i chciałam się odciązyć, bo ktoś mi powiedziat, że tak można na kasetach i pomyślatam: "O, będzie lizej". No i dostałam tę laske, wsadziłam ja głęboko gdzieś tam w szafkę, przy sprzataniu moja mama mówiła "Boże, schowaj to". Związek dawat laskę, ale za tym nie szły zajęcia $z$ orientacji... Ja nawet byłam na dwóch obozach letnich $z$ PZN-u i chyba nawet na jednym pokazano mi technike, jak laskę trzymać... Ale to wtedy było na zasadzie takiej zabawy...

Wskazana przez narratorkę kwestia była szerzej analizowana $\mathrm{w}$ szwedzkich badaniach prowadzonych w nurcie interpretatywnym poświęconych procesom uczenia się i zmianom związanym z utratą wzroku w biegu życia. W konkluzjach podkreślono, że biała laska ze względu na funkcję identyfikacyjną odgrywa aktywną rolę w interakcjach społecznych jej użytkownika, w związku z tym nauka posługiwania się nią $\mathrm{w}$ orientacji przestrzennej i lokomocji nie powinna być rozpatrywana jedynie przez pryzmat prostego korzystania z pomocy technicznej. Należy uwzględnić, że uczenie się technik poruszania się z laską oznacza także pewne przemiany w obszarze tożsamościowym, gdyż osoba z białą laską w przestrzeni publicznej jest a priori przypisywana do określonej grupy podlegającej stereotypizacji, nie zaś postrzegana jako autonomiczna jednostka ${ }^{24}$.

Interpretując dane z wywiadu, dostrzec można przynajmniej dwie formy nastawień do praktycznej pracy nad trajektorią i prób uzyskania nad nią kontroli ${ }^{25}$. Narratorka podejmowała próby

${ }^{24}$ I. Berndtsson, Förskjutna horisonter. Livsförändring och lärande $i$ samband med synnedsättning eller blindhet, University of Gothenburg, Göteborg 2001, s. 498-499.

25 Por. M. Górecki, Trajektoria, [w:] Encyklopedia Pedagogiczna XXI wieku. Tom VI, red. T. Pilch, Wydawnictwo Akademickie Żak, Warszawa 2007, s. 779. 
„oswojenia” trajektorii w codziennych działaniach, choć akceptacja niemożności usunięcia potencjału trajektoryjnego była długotrwała i nie przebiegała w sposób liniowy. Trudności obiektywnie wypływające $\mathrm{z}$ zaawansowania i rodzaju schorzenia były dodatkowo wzmacniane brakiem dostępu do profesjonalnego wsparcia informacyjnego ze strony rehabilitantów wzroku lub innych specjalistów umożliwiającego zrozumienie następstw funkcjonalnych posiadanego schorzenia i przyjęcie konstruktywnej postawy wobec doświadczanych problemów. Widoczne były także próby uwolnienia się z trajektorii głównie poprzez podejmowanie działań rehabilitacyjnych sprzyjających reorganizacji i poprawie sytuacji życiowej, co wiązało się m.in. z samodzielnym wyjazdem zagranicznym w celu zdobycia nowych kompetencji.

\section{Podsumowanie}

Wypowiedzi narratorki relacjonujące progres w chorobie były obszerne i koncentrowały się przede wszystkim na opisie następstw funkcjonalnych posiadanego schorzenia. Badana wyjaśniała ich istotę, podawała przykłady generowanych przez nie trudności, analizowała stopień ich prawidłowego rozumienia przez otoczenie społeczne. Ta wyraźna koncentracja w relacji na kwestiach stricte wzrokowych wydaje się przesłaniać proces przemian tożsamościowych, jakie musiały mieć miejsce na kolejnych etapach adaptacji do nabycia niewidzenia. Budowanie i interpretowanie tożsamości w obrębie trajektorii i poza nią pojawia się niejako $\mathrm{w}$ tle opowieści o zmianach w możliwościach posługiwania się wzrokiem.

Stopniowe nabywanie niewidzenia wiązało się z wieloma negatywnymi konsekwencjami, które okresowo obniżały subiektywne poczucie jakości życia osoby badanej. Mimo że postęp choroby prowadził czasami do przeciążenia mechanizmów psychicznej regulacji, utrudniał odgrywanie istotnych społecznie ról i wymagał podjęcia wieloletniego leczenia i rehabilitacji, to z obecnej perspektywy narratorka potrafiła dostrzec prorozwojowy potencjał do- 
świadczenia trajektoryjnego. Oceniała, że poprzez podjętą pracę nad trajektorią wzmocniła swoją odporność na sytuacje trudne, pogłębiła zdolność do refleksji, jak również doceniła wartość relacji interpersonalnych.

\section{Bibliografia}

Bartkowski J., Położenie społeczno-ekonomiczne i jakość życia osób niepełnosprawnych w Polsce, [w:] Polscy niepetnosprawni. Od kompleksowej diagnozy do nowego modelu polityki społecznej, red. B. Gąciarz, S. Rudnicki, Wydawnictwa Akademii Górniczo-Hutniczej, Kraków 2014.

Berndtsson I., Förskjutna horisonter. Livsförändring och lärande $i$ samband med synnedsättning eller blindhet, University of Gothenburg, Göteborg 2001.

Blaxter M., Zdrowie, przeł. M. Okła, Wydawnictwo Sic!, Warszawa, 2009.

Bury M., Illness narratives: fact or fiction? "Sociology of Health and Illness” 2001, nr 23.

Casten R., Rovner B., Depression in age-related macular degeneration, "Journal of Visual Impairment \& Blindness" 2008, vol. 102, nr 10.

Chrzanowska I., Pedagogika specjalna. Od tradycji do wspótczesności, Oficyna Wydawnicza „Impuls”, Kraków 2015.

Devine K., Reed-Knight B., Loiselle K., Fenton N., Blount R., Posttraumatic growth in young adults who experienced serious childhood illness: A mixed-methods approach, „Journal of Clinical Psychology in Medical Settings" 2010, nr 17, s. 340-348.

Flick U., Jakość w badaniach jakościowych, przeł. P. Tomanek, Wydawnictwo Naukowe PWN, Warszawa 2011.

Golemba B., Dostosowanie otoczenia do potrzeb dziecka słabo widzacego, "Niepełnosprawność i Rehabilitacja" 2007, nr 2, s. 71-80.

Goodley D., Disability Studies. An Interdisciplinary Introduction, MPG Books Group, Bodmin and King's Lynn, London 2011.

Górecki M., Trajektoria, [w:] Encyklopedia Pedagogiczna XXI wieku. Tom VI, red. T. Pilch, Wydawnictwo Akademickie Żak, Warszawa 2007.

Kos E., Wywiad narracyjny jako metoda badań empirycznych, [w:] Badania jakościowe w pedagogice. Wywiad narracyjny i obiektywna hermeneutyka, red. D. Urbaniak-Zając, E. Kos, Wydawnictwo Naukowe PWN, Warszawa, 2013.

Majewski T., Tyflopsychologia rozwojowa. Psychologia dzieci niewidomych i stabo widzacych, Polski Związek Niewidomych, Warszawa, 2002.

Oleś P., Oleś M, Poczucie jakości życia u pacjentów chorych na zaćmę, [w:] Jak świata mniej widzę: zaburzenia widzenia a jakość życia, red. P. Oleś, S. Steuden, J. Toczołowski, Towarzystwo Naukowe Katolickiego Uniwersytetu Lubelskiego, Lublin 2002. 
Rudnicki S., Niepetnosprawność i złożoność, „Studia Socjologiczne” 2014, nr 2(213).

Stanikowska, E., Psychologiczne aspekty stabowzroczności, „Kontaktologia i Optyka Okulistyczna" 2008, nr 3(19).

Steuden S., Poczucie jakości życia u pacjentów chorych na jaskrę, [w:] Jak świata mniej widzę: zaburzenia widzenia a jakość życia, red. P. Oleś, S. Steuden, J. Toczołowski, Towarzystwo Naukowe Katolickiego Uniwersytetu Lubelskiego, Lublin 2002a.

Steuden S., Z psychologicznej problematyki zdrowia i choroby, [w:] Jak świata mniej widzę: zaburzenia widzenia a jakość życia, red. P. Oleś, S. Steuden, J. Toczołowski, Towarzystwo Naukowe Katolickiego Uniwersytetu Lubelskiego, Lublin 2002b.

Soroko E., Wywotywanie autonarracji w badaniach psychologicznych. Ocena (auto)narracyjności wypowiedzi, Wydawnictwo Naukowe Uniwersytetu Adama Mickiewicza, Poznań 2009.

Tinkle B.T., Saal H.M., the Committee on Genetics, Health Supervision for Children With Marfan Syndrome, „Pediatrics” 2013, Vol. 132, nr 4.

Walkiewicz-Krutak M., Stabowzroczność w aspekcie klinicznym i funkcjonalnym, [w:] Tyflopedagogika wobec wspótczesnej przestrzeni edukacyjno-rehabilitacyjnej, red. K. Czerwińska, M. Paplińska, M. Walkiewicz-Krutak, Wydawnictwo Akademii Pedagogiki Specjalnej, Warszawa 2015.

Walthes R., Einführung in die Blinden- und Sehbehindertenpädagogik, Reinhardt Verlag, München 2005.

Wortman C.B., Posttraumatic growth: Progress and problems, „Psychological Inquiry” 2004, nr 15.

Yin R.K., Studium przypadku w badaniach naukowych. Projektowanie i metody, przeł. J. Gilewicz, Wydawnictwo Uniwersytetu Jagiellońskiego, Kraków 2015.

Zaorska M., Tyflopedagog wobec problemu aktywności życiowej - zawodowej i prozawodowej osób dorostych z niepetnosprawnościq wzrokową, Wydawnictwo Edukacyjne Akapit, Torun 2015. 